\title{
E-Textbooks and Their Application Levels, from the Perspective of Faculty Members at Ajman University, U.A.E.
}

\author{
https://doi.org/10.3991/ijet.v14i13.9489 \\ Mohd. Elmagzoub Eltahir ${ }^{\varpi}$, Sami Al-Qatawneh, Najeh Alsalhi \\ Ajman University, Ajman, UAE \\ m.babiker@ajman.ac.ae
}

\begin{abstract}
The aim of this study is to identify the effectiveness of the use of e-textbooks implemented in undergraduate programs at Ajman university from the faculty member's perspective. The quantitative study applied an analytical descriptive approach on faculty member's participants (128) from a variety of colleges, in the first academic semester of 2017/2018. The results of the study showed that there is a medium degree of application of e-textbooks and that etextbooks have an average medium impact on student achievement. The results also showed that the degree of application vary from the perspective of faculty members' according to gender which was in favor of the female, and according to college variable was in favor of the Business Administration college. Further, the results showed that there are not statistically significant differences according to Academic rank variable and experience variable. The faculty members agree on the need to develop and improve the features and requirements of e-textbooks that have been applied. The findings led to recommendations including the implementation of a training program on e-textbooks for the faculty members' and students focusing on the features applications and options of e-textbooks.
\end{abstract}

Keywords-E-Textbooks, E-learning, Higher Education, Ajman University

\section{Introduction}

The world is recently witnessing a rapid scientific and technical leap, especially as we enter the twenty-first century, which has reflected our lives in all of its different aspects, such as health, social, educational, political, economic and other fields. One of the important fields in which modern technology has played a significant role in changing and developing are teaching and learning. Plangsorn and Poopan [1] stated that in our daily lives there is more progressive educational technology, due to the rapid development of ICTs. Today's many sources of learning such as, E-books, social media, virtual classes, and massive open online courses (MOOC) are available to both educators and learners. This is confirmed by Thomas [2] where he pointed out, that the adoption of digital textbooks or e-textbooks in schools and universities is expected to grow at a high rate. 
With the introduction of E-learning, the learners were able to become autonomous learners. Students through E -learning can access educational curricula whenever they need it through modern technology, which is the main basis of the educational philosophy behind e-learning. E-learning environments are often used in higher education as support for learning processes and teaching in different aspects and levels of knowledge [3], [4]. E-textbook is one of this new technology which will replace existing printed textbooks in the e-learning environment [5]. Khalid., et al. [6] said that electronic books had received rapid acceptance within both higher education and preuniversity institutions around the world as the preferred form of educational resources. Therefore, in tandem with the aims and objectives of Ajman university which includes the inculcation of modern technology in educating and equipping the leaders of tomorrow, the university emphasizes on e-learning in order to increase the quality and effectiveness of education. Recently the university saw a shift to implement such aims through the introduction of e-textbooks as an alternative to books. All colleges and Departments were required to shift their course textbooks to the e-textbook as a top down policy enactment. Faculty and students were given encouragement from university management to shift to his new approach to teaching and learning in order to make it as smooth and successful as possible. The change occurred across one semester at the university from introduction to implementation and all faculty members were required to adopt to this new approach of teaching and learning.

\section{Study Problem and Questions}

Problems of learning crystallized when Ajman university started developing its educational and electronic services through the application of e-books instead of printed books. The researchers noted that there were a number of faculty members who expressed their satisfaction and conviction of the advantages and importance of using e-books in their courses within the university. At the same time, there are others who believe that the e-book use is not that important, and that they do not interact with them in a positive form, and that the e-books don't benefit them academically. Therefore, the research came to answer the following questions:

- How do faculty members perceive the effectivity of e-textbooks in undergraduate programs at Ajman university?

- How has e-textbooks affected the achievement level of students at Ajman university?

- What features can be considered to improve the e-textbook experience in undergraduate programs at Ajman university?

- How do faculty members view the importance of e-book requirements in supporting the learning of students?

- Does the degree of application of e-textbooks at Ajman University vary from the perspective of faculty members' perspective according to gender, college, academic rank and experience? 


\section{The Importance of the Study}

- Providing the officials and decision makers at Ajman university with the necessary feedback about the application of e-textbooks in university, through enhancing the points of strengths and working on the aspects that need improvement and modification.

- Provide the institutions of higher education and pre-university education with information that benefits them in their practical and developmental procedures in the field of application of the e-textbooks as alternative curriculum to the printed one.

- Precedence of the research, which is considered the first research aimed to investigating the views of member's faculty about the use of e-textbooks.

\section{$4 \quad$ Aims of the Study}

This research aims to:

- Identify the effectiveness of the use of e-textbooks at Ajman university from the perspective of faculty members.

- Examine, the perspective of members of faculty, at Ajman university on the application of e-textbooks and the integration of technology in learning.

- Focus in particular on the challenges and advantages of using e-textbooks in various undergraduate programs at Ajman university.

\section{$5 \quad$ Literature Review}

Higher education institutions around the world are now more amenable to etextbooks, considering them the preferred form of text resources for learning in these institutions. According to [7] the first visible appearance of e-textbooks in higher education institutions was in the year of 1971, during Gutenberg Project. According to [1], [8], there are two types of e-textbooks:

- e-books in an electronic environment contains contents including texts and digital objects features.

- The e-books contain text, and advanced techniques like hyperlinks, multimedia highlights and note taking and other features.

As shown by several studies [9], [10], [11] there are several features of e-textbooks such as

- Multiple e-books can be stored on a single electronic device

- e-books offer the ability to conduct fast electronic searches on the text or resume reading on a different device than what was used initially

- Users can quickly download books from virtually any location-books are less expensive than paper books 
- e-books are more environmentally friendly than printed books

- e-books can be read with numerous devices and tools

[11] mention that student's preferred e-textbooks more than printed paper books because there is a wider range of titles that students can choose from as well as having the advantage of texts available to them. In higher education, e-textbooks are progressively playing a central role in teaching, learning and research, as they help increase access to timely and diverse scholarly material, so most of academic libraries now provide e-textbook access to their students [12].

There have been many studies on the use of e-textbooks in education. [13] conducted study aimed to keep pace with the rapid developments in the field of e-learning through the use of e-textbooks at the university of Princess Nora in Saudi Arabia. The researchers conducted a study on (55) different faculty members, and (44) female students, the results showed that the faculty members, emphasized the importance of ebooks in education and the need for them. Students have the basic skills to download, read and take advantage and features of e-textbooks. Also in study by [6] aimed at investigating student's views about the e-textbooks used in Sultan Qaboos university, the study used the quantitative design and a questionnaire that was distributed electronically to the students. Results of the study show that the students at Sultan Qaboos university have several and different experiences with e-books but do not prefer e-books over printed books in their academic studies. The study also found that the students need more time and encouragement to change their attitudes and preferences to start using e-books instead of the printed paper books. In another study by [1] which aimed to improve the efficiency of e-books use by teachers in Chachengsao city in Thailand and to know the impact of using e-books by teachers in the schools of the city. They used qualitative and quantitative methods to interview participants. The results showed that there is positive impact on the students' behavior and attention because of the use of e-books by teachers in teaching. Moreover, [14] study, which examined the effect of interactive e-book on students' achievement at Najran university, Saudi Arabia in computer education courses, the sample of the semi-experimental study of (60) students were divided equally into two experimental and control groups. The results of the study showed that there were statistically significant differences between the study groups in the achievement of the study for the benefit of the students of the experimental group who studied using the e-book. [15] also conducted a study aimed at identifying pre-service teachers' views about e-books and their general knowledge and related technological tools. The sample of study consisted of 543 students (233) male students and (310) female students. The results demonstrated an increase in the use of e-books according to the students' levels, and that the levels of general knowledge of social science students on e-books were lower compared to students of science, mathematics and foreign languages.

On the other side study conducted by [16] indicated that students at the university have faced difficulties in the use of e-textbooks when performing a number of tasks related to remembering and retrieving information, and the use of certain characteristics it. In the Oliveira study [17], the aim was to uncover the attitudes and patterns of the students' use of e-books at Andrews university, and the impact of their use on learning 
through a questionnaire that was distributed on the students. The questionnaire was distributed to (503) students. The study concluded that a small percentage (4\%) adopted the idea of using e-books and that the printed and paper books are still very much preferred by the students. It also concluded that the lack of awareness of how to access and use e-books were the reasons behind the lack of preference of the e-books. A review of the previous researches and educational literature, shows that studies that talked about the experience of applying e-textbooks in universities and schools are not yet sufficient to ensure their success and effectiveness in teaching and learning to become a substitute for printed and widely used paper books in universities, government and private schools and the educational sector in general. The results of some studies have shown that the use of e-textbooks has had a positive effect on both achievement level [1], [11], [13], [14], [15]. At the same time, other studies have shown a lack of acceptance and encouragement to use e-textbooks compared to traditional books such as in the research study of [6], [16], [17]. Hence, the researchers at Ajman university concluded that this experiment should be applied to the courses taught by various faculties in the university, who previously taught through printed paper books to find out which of the perspectives was mirrored as a result of the recent switch to etextbooks.

\section{$6 \quad$ Methodology and Procedures}

\subsection{Participants}

The participants of this study are comprised of all faculty members in the collages of Dentistry, Pharmacy \& Health Sciences, Engineering, Information Technology, and Business administration, in the first semester of academic year 2017/2018, the total number are (148). The researchers taking (20) faculty members as pilot study to calculate the coefficient of the study instrument reliability, thus the participants are (128) of faculty members, the Demographic Information as shown in table 1. 
Table 1. Demographic Information of Faculty Members

\begin{tabular}{|l|l|c|c|}
\hline Study Variable & \multicolumn{1}{|c|}{ Variables levels } & Frequency (f) & Percentage (\%) \\
\hline \multirow{5}{*}{ Gender } & Female & 74 & $57.8 \%$ \\
\cline { 2 - 4 } & Male & 54 & $42.2 \%$ \\
\cline { 2 - 4 } & Total & 128 & $100 \%$ \\
\hline \multirow{5}{*}{ College } & College of Dentistry & 38 & $29.7 \%$ \\
\cline { 2 - 4 } & College of Pharmacy \& Health Sciences & 13 & $10.2 \%$ \\
\cline { 2 - 4 } & College of Engineering & 51 & $39.8 \%$ \\
\cline { 2 - 4 } & College of Information Technology & 10 & $7.8 \%$ \\
\cline { 2 - 4 } & College of Business Administration & 16 & $12.5 \%$ \\
\cline { 2 - 4 } & Total & 128 & $100 \%$ \\
\hline \multirow{5}{*}{ Ecademic rank } & Professor & 11 & $8.6 \%$ \\
\cline { 2 - 4 } & Associate Professor & 31 & $24.2 \%$ \\
\cline { 2 - 4 } & Assistant Professor & 47 & $36.7 \%$ \\
\cline { 2 - 4 } & Lecturer & 39 & $30.5 \%$ \\
\cline { 2 - 4 } & Total & 128 & $100 \%$ \\
\hline & Less than 5 years & 11 & $8.6 \%$ \\
\cline { 2 - 4 } & 5-10 years & 41 & $32.0 \%$ \\
\cline { 2 - 4 } & More than 10 years & 76 & $59.4 \%$ \\
\cline { 2 - 4 } & Total & 128 & $100 \%$ \\
\hline
\end{tabular}

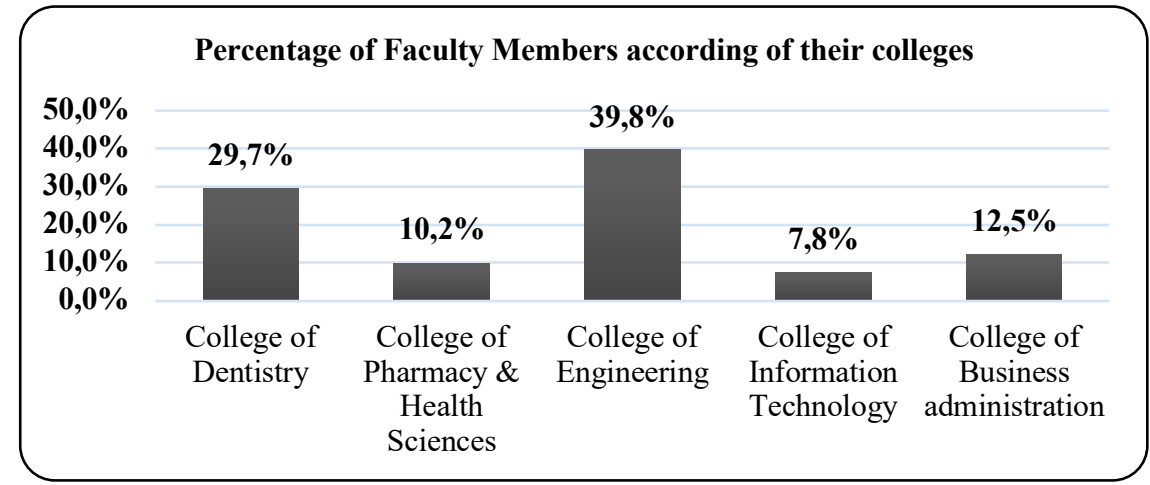

Fig. 1. Participants of the Faculty Members

\subsection{Tools}

A two parts survey has been used as the main instrument for this study. The researchers benefited from previous studies in building the tool [6], [18]. The first part of the survey includes the background Information of faculty members. As for the second part of the survey, there were four items (Using Electronic E-Textbook, Academic Achievement, Electronic Textbooks Features, Electronic Textbooks Requirements) with five-scale Likert scale (Strongly Agree= 5, Agree=4, Neutral = 3, Disagree $=2$, and Strongly Disagree $=1$.) to determine the participants' views about implementation of electronic textbooks. Then those answers categorized into equal five range levels through following equation: the length of category $=$ (maximum value minimum value $) \div$ number of alternatives $=(5-1) \div 5=0.80$, as Shown in table 2 . 
Table 2. Distribution of categories

\begin{tabular}{|l|c|}
\hline \multicolumn{1}{|c|}{ Description } & Extent of Means \\
\hline Strongly Agree & $4.21-5.00$ \\
\hline Agree & $3.41-4.20$ \\
\hline Neutral & $2.61-3.40$ \\
\hline Disagree & $1.81-2.60$ \\
\hline Strongly Disagree & $1.00-1.80$ \\
\hline
\end{tabular}

\subsection{Validity of tools}

The tool was confirmed by Virtual validity method, after gaining the permission from Deanship of Graduate Studies and Research, by check the validity of the content of the research tools, they were being displayed after designing on a group of arbitrators, experts in the fields of psychology, teaching methods and education technology. They were being asked to express their opinions in terms of the appropriateness of its clauses to achieve the objectives of the study and the adequacy of the tools in terms of the number of items and comprehensiveness and the diversity of content and evaluating the language in addition to any other comments they see fit to optimize and improve the level of research tools.

\subsection{Reliability of tools}

The researchers verified the reliability of the tools by application of the research tools on pilot sample consists from 20 faculty members from outside of the research sample by using two methods: The first method was verified by using the Cronbach alpha coefficient through the SPSS program where its value for the questionnaire was $(0.84)$.

Table 3. Alpha Cronbach's coefficients of reliability for the questionnaire dimensions of the effectiveness of application e-textbooks

\begin{tabular}{|l|c|c|}
\hline \multicolumn{1}{|c|}{ Dimension } & No. of items & Reliability Coefficient of Alpha Cronbach \\
\hline Using Electronic E-Textbook & 7 & 0.83 \\
\hline Academic Achievement & 9 & 0.85 \\
\hline Electronic Textbooks Features & 11 & 0.88 \\
\hline Electronic Textbooks Requirements & 5 & 0.81 \\
\hline Total reliability & 32 & 0.84 \\
\hline
\end{tabular}

And second method by using the (Test- Retest) method, the research tool was applied to (20) from outside the sample of the research with a time difference between the two periods of two weeks, the researchers used the Pearson Correlation. 
Table 4. Reliability coefficients for the questionnaire dimensions of the effectiveness of application e-textbooks by (Test- Retest) method.

\begin{tabular}{|l|c|c|}
\hline \multicolumn{1}{|c|}{ Dimension } & No. of items & Reliability Coefficient \\
\hline Using Electronic Textbook & 7 & 0.87 \\
\hline Academic Achievement & 9 & 0.85 \\
\hline Electronic Textbooks Features & 11 & 0.84 \\
\hline Electronic Textbooks Requirements & 5 & 0.86 \\
\hline Total reliability & 32 & 0.85 \\
\hline
\end{tabular}

\section{$7 \quad$ Results and Discussion}

First question: How do faculty members perceive the effectivity of e-textbooks in undergraduate programs at Ajman university? To answer this question, the means computations and standard deviations of the responses of the research sample of faculty members were calculated on each item of the instrument and were arranged in descending order according to their means, as shown in table 5.

Table 5. Means and standard deviation arranged in descending order for the responses of the Faculty Members about the effective of using e-text books.

\begin{tabular}{|c|c|c|c|c|c|}
\hline No & Items & Mean & S. Deviation & Order & Description \\
\hline 1 & $\begin{array}{l}\text { Students depend on E-textbooks during their studies } \\
\text { and their exams. }\end{array}$ & 2.53 & 1.055 & 6 & Neutral \\
\hline 2 & $\begin{array}{l}\text { Students were able to read the electronic version of the } \\
\text { printed books easily through a computer or a handheld } \\
\text { device specifically designed for this purpose. }\end{array}$ & 3.02 & 1.137 & 4 & Neutral \\
\hline 3 & $\begin{array}{l}\text { Students do not have difficulty accessing E-textbooks } \\
\text { content. }\end{array}$ & 2.97 & 1.140 & 5 & Neutral \\
\hline 4 & Students can write notes on e-textbooks. & 3.27 & .955 & 2 & Neutral \\
\hline 5 & $\begin{array}{l}\text { Students faced difficulties in their use of E-textbooks } \\
\text { due to lack of experience and training. }\end{array}$ & 3.27 & 1.083 & 2 & Neutral \\
\hline 6 & $\begin{array}{l}\text { Students prefer to use E-textbooks and printed paper } \\
\text { books together during their undergraduate studies }\end{array}$ & 3.22 & 1.304 & 3 & Neutral \\
\hline 7 & $\begin{array}{l}\text { Students do not feel comfortable while using E- } \\
\text { textbooks. }\end{array}$ & 3.49 & 1.130 & 1 & Agree \\
\hline \multicolumn{2}{|c|}{ Total mean for dimension } & \multicolumn{4}{|c|}{3.11} \\
\hline \multicolumn{2}{|c|}{ Standard deviation } & \multicolumn{4}{|c|}{1.11} \\
\hline
\end{tabular}

The results on table 5 indicates that the general arithmetic mean of the first dimension which is (using electronic textbook) is the level of Medium, which mean the application of e-textbooks by the students according to perspective of faculty members, was Medium, and it was (3.11), where Means research sample responses of faculty members ranged between (2.53 - 3.49), and their order between dimensions in terms of arithmetic mean is the forth. As the table shows that item 7, which states (Students do not feel comfortable while using E-textbooks) has received the highest average arithmetic (3.49), this may be because students did not have enough experience and training to handle e-textbooks from before, and the lowest average arithmetic for the item 1, which states (Students depend on E-textbooks during their studies and their 
exams.), which it was value (2.53), which means that the students did not rely much on their e-textbooks, this may be because students did not have enough information about the features of e-textbooks to help them in their study and to write notes easily.

The result of this dimension and the reasons to a medium degree of e-textbooks application, may be explained by the fact that the students did not have enough experience to use e-textbooks and they were accustomed to studying through printed books, not e-textbooks. In addition, the lack of prior training for students and their lack of knowledge of e-book features. This result is consistent with the three studies of [6], [16], [17], which their results emphasize the low of application of electronic textbooks efficient and point out also that the students do not prefer e-textbooks over printed books in their academic studies. Whereas other studies [1], [11] [13], [14] their results emphasize the good application efficiency of electronic textbooks by the students.

Second question: How has e-textbooks affected the achievement level of students at Ajman university? To answer this question, the means computations and standard deviations of the responses of the research sample of faculty members were calculated on each item of the instrument and were arranged in descending order according to their means, as shown in table 6 .

Table 6. Means and standard deviation arranged in descending order for the effective of application of e- textbooks on students 'achievement.

\begin{tabular}{|c|l|c|c|c|c|}
\hline No. & \multicolumn{1}{|c|}{ Items } & Mean & S. Deviation & Order & Description \\
\hline 1 & $\begin{array}{l}\text { E-textbooks increase students' achievements due to } \\
\text { the availability of multimedia with content }\end{array}$ & 2.87 & 1.04 & 7 & Neutral \\
\hline 2 & $\begin{array}{l}\text { The E-textbook makes the teaching process interesting } \\
\text { and stimulating for learning and teaching }\end{array}$ & 3.03 & 1.05 & 5 & Neutral \\
\hline 3 & $\begin{array}{l}\text { The E-textbook increases the effectiveness of learning } \\
\text { because it depends on multiple educational media }\end{array}$ & 2.93 & 1.08 & 6 & Neutral \\
\hline 4 & $\begin{array}{l}\text { Students interact with the E-textbook more than the } \\
\text { printed book, which is called (silent teacher) }\end{array}$ & 2.31 & 1.00 & 8 & Disagree \\
\hline 5 & $\begin{array}{l}\text { E-textbooks increases student understanding by } \\
\text { teaching scientific and practical materials using } \\
\text { different multimedia such as virtual labs and video } \\
\text { clips. }\end{array}$ & 2.93 & 1.02 & 6 & Neutral \\
\hline 6 & $\begin{array}{l}\text { E-books provide direct interaction with the content of } \\
\text { the course and increase self-learning for students. }\end{array}$ & 3.06 & 0.98 & 4 & Neutral \\
\hline 7 & $\begin{array}{l}\text { The use of E-textbooks by students gives them fair } \\
\text { and equal opportunities in terms of availability with all } \\
\text { students at the same time. }\end{array}$ & 3.31 & 0.95 & 1 & Neutral \\
\hline 8 & $\begin{array}{l}\text { Using E-textbooks can help teachers explain complex } \\
\text { and abstract concepts. }\end{array}$ & 3.10 & 1.08 & 3 & Neutral \\
\hline 9 & $\begin{array}{l}\text { Integrating E-textbooks into teaching can help } \\
\text { teachers become more flexible and enhance students } \\
\text { participation. }\end{array}$ & 3.18 & 1.13 & 2 & Neutral \\
\hline Total mean for dimension & & & 2.97 & 1.04 & \\
\hline Standard deviation & & & & \\
\hline
\end{tabular}

The results on table 6 indicates that the general arithmetic mean of the second dimension which is (Academic Achievement) is the level of Medium, this means that e-textbooks have medium impact on student achievement according to perspective of 
faculty members, and it was (2.97), which means that the students have medium academic achievement effectiveness by the application of e- textbooks in the undergraduate programs. Where Means research sample responses of faculty members ranged between (2.31-3.31), and their order between dimensions in terms of arithmetic mean is the third. As the table shows that item 14, which states (The use of E-textbooks by students gives them fair and equal opportunities in terms of availability with all students at the same time) has received the highest average arithmetic (3.31), the reason according to the view of researchers, maybe due to the fact that all students take the same curricula, topics, exams, worksheets which all depended on e-textbooks which were given for all students at the same time. Where the lowest average arithmetic for the item 11, which states (Students interact with the E-textbook more than the printed book, which is called silent teacher) which it was value (2.31), the reason according view of researchers, may be due to that weak trend and encouragement students to use e-textbooks as an alternative of traditional printed textbooks. This confirming that students of Ajman university during the first semester of 2017/2018 have medium academic achievement effectiveness by the application of e- textbooks in the undergraduate programs. On the other hand, this result is consistent with the study of [6], [17], which showed that the students have several and different experiences with etextbooks but do not prefer e-textbooks over printed books in their academic studies more encouragement to change their attitudes and preferences to start using e-textbooks instead of the printed books. So, the use of e-textbooks did not make a difference in academic achievement. Whereas other study [19], which concluded that the e-textbook has succeeded in improving children's understanding and knowledge. Also, the study by [14] showed that there were statistically significant differences between the study groups in the achievement of the study for the benefit of the students of the experimental group who studied using the e-textbook.

Third question: What features can be considered to improve the e-textbook experience in undergraduate programs at Ajman university? To answer this question, the means computations and standard deviations of the responses of the research sample of faculty members were calculated on each item of the instrument and were arranged in descending order according to their means, as shown on table 7.

The results on table 7 indicates that the general arithmetic mean of the third dimension which is (Electronic Textbooks Features) is the level of Agree, and the value of mean was (3.57); Where Means research sample responses of faculty members ranged between (3.12 - 4.01), and their order between dimensions in terms of arithmetic mean is the second.

As the table shows that item 26, which states (E-textbooks are environmentally friendly by reducing pollution and paper waste) has received the highest average arithmetic (4.01), the reason according view of researchers, maybe due to the material for electronic books which is a software, and not paper, which is different from the traditional printed books which needs material raw taken from forests and causing Imbalance of the vegetation. 
Table 7. Means and standard deviation arranged in descending order according to the features of a good e- textbooks.

\begin{tabular}{|c|c|c|c|c|c|}
\hline No. & Items & Mean & Standard Deviation & Order & Description \\
\hline 1 & $\begin{array}{l}\text { It is easy to transfer and download E- } \\
\text { textbook on various devices. }\end{array}$ & 3.33 & .99 & 9 & Neutral \\
\hline 2 & Electronic textbooks saves time and effort. & 3.38 & .98 & 8 & Neutral \\
\hline 3 & $\begin{array}{l}\text { E-textbook contains multiple media such as } \\
\text { pictures, video clips, animation, and various } \\
\text { sound effects, and also high interactive } \\
\text { features through links and programs. }\end{array}$ & 3.57 & .89 & 6 & Agree \\
\hline 4 & $\begin{array}{l}\text { The E-textbook allows the content to be } \\
\text { displayed in the classroom using the LCD, } \\
\text { Data show, and data display unit }\end{array}$ & 3.66 & .83 & 4 & Agree \\
\hline 5 & $\begin{array}{l}\text { Electronic books are less expensive for } \\
\text { students than printed books. }\end{array}$ & 3.29 & 1.18 & 10 & Neutral \\
\hline 6 & $\begin{array}{l}\text { Backups of E-textbooks can be saved for } \\
\text { retrieval in case of loss or damage }\end{array}$ & 3.63 & 1.02 & 5 & Agree \\
\hline 7 & $\begin{array}{l}\text { The E-textbook may cause harm to the eye } \\
\text { because of the concentration during the } \\
\text { reading process through the screen of the } \\
\text { device. }\end{array}$ & 3.95 & 1.05 & 2 & Agree \\
\hline 8 & $\begin{array}{l}\text { The E-textbook has the ability to search and } \\
\text { access any text in content, or a word or part } \\
\text { of text or certain pages at high speed. }\end{array}$ & 3.75 & .93 & 3 & Agree \\
\hline 9 & $\begin{array}{l}\text { E-textbook forms are suitable for all student } \\
\text { groups, including those with disabilities }\end{array}$ & 3.12 & 1.04 & 11 & Neutral \\
\hline 10 & $\begin{array}{l}\text { E-textbooks are environmentally friendly by } \\
\text { reducing pollution and paper waste. }\end{array}$ & 4.01 & .92 & 1 & Agree \\
\hline 11 & $\begin{array}{l}\text { It is easy to update and modify E-textbook } \\
\text { content at no extra cost. }\end{array}$ & 3.54 & .97 & 7 & Agree \\
\hline \multicolumn{2}{|c|}{ Total mean for dimension } & \multicolumn{4}{|c|}{3.57} \\
\hline \multicolumn{2}{|c|}{ Standard deviation } & \multicolumn{4}{|c|}{.98} \\
\hline
\end{tabular}

Where the lowest average arithmetic for the item 25, which states (E-textbook forms are suitable for all student groups, including those with disabilities). Which it was value (3.12), the reason is may be due to weak knowledge and understanding the features or properties of e-textbooks.

The result of this dimension can explain that the faculty members agree that the features of e-textbooks needs to be developed and improve further in order provide the best applied experience for both students and faculty. On other hand, there are many studies which confirm the features of e-textbooks [9], [10], [11]. All of these studies point to the importance of features of e-textbooks in teaching and learning and show the direct relationship between the understanding of taught material and academic achievement through the implementation of these features.

Fourth question: How do faculty members view the importance of e-book requirements in supporting the learning of students? To answer this question, the means computations and standard deviations of the responses of the research sample of faculty members were calculated on each item of the instrument and were arranged in descending order according to their means, as shown on table 8. 
Table 8. Means and standard deviation arranged in descending order according for the requirements of e- textbooks.

\begin{tabular}{|c|l|c|c|c|c|}
\hline No. & \multicolumn{1}{|c|}{ Items } & Mean & $\begin{array}{c}\text { Standard } \\
\text { Deviation }\end{array}$ & Order & Description \\
\hline 1 & $\begin{array}{l}\text { E-textbooks should include learning } \\
\text { outcomes/assessment and } \\
\text { measurement/educational content/course } \\
\text { activities, learner interaction/learner support/use } \\
\text { of techniques in the course. }\end{array}$ & 3.98 & .902 & 5 & Agree \\
\hline 2 & $\begin{array}{l}\text { Each E-textbook should contain a guide to the } \\
\text { student about the full description of the } \\
\text { activities, multimedia, and assessment methods. }\end{array}$ & 4.08 & .694 & 4 & Agree \\
\hline 3 & $\begin{array}{l}\text { E-textbooks should not only be a copy of the p- } \\
\text { books, but should be more developed and } \\
\text { improved to where they include helping tools } \\
\text { that allow more students' interaction; such as, } \\
\text { (highlighting, copying, pasting, and making } \\
\text { comments) }\end{array}$ & 4.21 & .678 & 3 & $\begin{array}{c}\text { Strongly } \\
\text { Agree }\end{array}$ \\
\hline 4 & $\begin{array}{l}\text { Printing options should be made available with } \\
\text { E-textbooks. }\end{array}$ & 4.35 & .677 & 1 & $\begin{array}{c}\text { Strongly } \\
\text { Agree }\end{array}$ \\
\hline 5 & $\begin{array}{l}\text { Educational content in E-textbooks should be } \\
\text { appropriate for students' skills and their } \\
\text { individual differences. }\end{array}$ & 4.25 & .706 & 2 & $\begin{array}{c}\text { Strongly } \\
\text { Agree }\end{array}$ \\
\hline Total mean for dimension & & & 4.18 & .73 & \\
\hline Standard deviation & & & & \\
\hline
\end{tabular}

The results on table 8 indicates that the general arithmetic mean of the fourth dimension which is (Electronic Textbooks Requirements) was agree and the value of mean was (4.18); Where Means research sample responses of faculty members ranged between $(3.98-4.35)$, and their order between dimensions in terms of arithmetic mean is the first. As the table shows that item 31, which states (Printing options should be made available with e-textbooks.) has received the highest average arithmetic (4.35), the reason according to researchers, may be due to students always needing to print some texts, items, forms, tables or even some illustrations images that benefit them. The existence of flexible and varied options to print any part of the e-textbook is an essential requirement for e-textbooks, in addition to other e-textbooks requirements. The lowest average arithmetic for the item 28, which states (E-textbooks should include learning outcomes/assessment and measurement/educational content/course activities, learner interaction/learner support/use of techniques in the course). The value is (3.98), the reason may be due to lack of knowledge and understanding of faculty members for requirements of Authoring, designing and developing e-books through electronic curriculum experts, the presence of learning outcomes / assessment and measurement / instructional content / course activities, learner interaction / learner support / modern techniques which are important criteria and should be exists in e-textbooks. The researchers believe that the result of this dimension can be explained by the fact that all faculty members agree on the need for e-textbooks requirements. Therefore, the university should review this subject in order to ensure that all requirements are available in accordance with international standards that faculty and students can use of e-books easily in the coming chapters. 
Fifth question: Does the degree of application of e-textbooks at Ajman University vary from the perspective of faculty members' perspective according to gender, college, academic rank and experience? Mean scores and standard deviations were calculated to answer the study's fifth question. Analysis of the independent T-test and variance test was conducted to find out the significance of differences between averages. Scheffe's test for Post hoc comparisons were conducted to find the significance of differences between means. The results of the responses of the study subjects are detailed below according to the study variables are shown as follows:

- Gender: The independent sample test $(\mathrm{T})$ was used to find out the significance of the differences between averages of the degree of application of e-textbooks at Ajman University, from the perspective of faculty members according to gender (see table 9).

Table 9. The Means and standard deviation of the faculty members' responses according to gender

\begin{tabular}{|l|c|c|c|c|c|c|}
\hline \multicolumn{1}{|c|}{ Gender } & N & Mean & Std Deviation & T. Value & Sig (tailed) & Sig. level \\
\hline Male & 74 & 4.2031 & 0.65295 & -2.504 & $0.014^{*}$ & Significant \\
\cline { 1 - 6 } Female & 54 & 4.4766 & 0.58030 & & & \\
\hline
\end{tabular}

* Statistically significant at $(\alpha \leq 0.05)$

The results of the table 9 indicate that the ( $\mathrm{t}$ ) computed value was (-2.504), which is larger than the $(\mathrm{t})$ table, which means there are significant differences at the significance level of $(0.014)$ and is less than the required statistical significance level (0.05); between the mean value of Male and Female, a favor of the Female.

- College: Relating to college, Table 10 Shows the resulting Analysis of variance according to college variable by One Way ANOVA test for the faculty members' responses.

Table 10. Analysis of variance according to college variable by One Way ANOVA test.

\begin{tabular}{|c|l|c|c|c|c|c|c|}
\hline & & $\begin{array}{c}\text { Sum of } \\
\text { Squares }\end{array}$ & df & $\begin{array}{c}\text { Mean } \\
\text { Square }\end{array}$ & Sig. level & $\begin{array}{c}\text { Sig } \\
\text { (tailed) }\end{array}$ & F \\
\hline \multirow{2}{*}{ College } & $\begin{array}{l}\text { Between } \\
\text { Groups }\end{array}$ & 5.534 & 4 & 1.384 & \multirow{2}{*}{$0.006^{*}$} & \multirow{2}{*}{3.788} & Significant \\
\cline { 2 - 5 } & $\begin{array}{l}\text { Within } \\
\text { Groups }\end{array}$ & 44.932 & 123 & .365 & & & \\
\cline { 2 - 5 } & Total & 50.467 & 127 & & & \\
\hline
\end{tabular}

* Statistically significant at $(\alpha \leq 0.05)$

It is clear from Table 10 that there are statistically significant differences at the level of (0.006) and is less than the required statistical significance level (0.05); from the perspective of faculty members' according to college variable. To determine the source of the differences, Schiffe test was used for the following comparisons, and their results are shown in Table 11: 
Table 11. The resulting of Scheffe Test to identify the source of differences of the faculty members' responses according to college variable.

\begin{tabular}{|c|c|c|c|c|c|c|}
\hline \multirow[b]{2}{*}{ (I) The college } & \multirow[b]{2}{*}{ (J) The college } & \multirow{2}{*}{$\begin{array}{c}\text { Mean } \\
\text { Differen } \\
\text { ce }(\mathbf{I}-J)\end{array}$} & \multirow[b]{2}{*}{ Std. Error } & \multirow[b]{2}{*}{ Sig. } & \multicolumn{2}{|c|}{$\begin{array}{l}\text { 95\% Confidence } \\
\text { Interval }\end{array}$} \\
\hline & & & & & $\begin{array}{l}\text { Lower } \\
\text { Bound }\end{array}$ & $\begin{array}{l}\text { Upper } \\
\text { Bound }\end{array}$ \\
\hline \multirow[t]{4}{*}{ Dentistry } & $\begin{array}{l}\text { Pharmacy \& Health } \\
\text { Science }\end{array}$ & .25376 & .18896 & .182 & -.1203 & .6278 \\
\hline & Business Administration & -.11678 & .18012 & .518 & -.4733 & .2398 \\
\hline & Engineering & $.38947 *$ & .13007 & .003 & .1320 & .6469 \\
\hline & Information Technology & $.43947^{*}$ & .21481 & .043 & .0143 & .8647 \\
\hline \multirow{4}{*}{$\begin{array}{l}\text { Pharmacy } \\
\text { \&Health } \\
\text { Science }\end{array}$} & dentistry & -.25376 & .18896 & .182 & -.6278 & .1203 \\
\hline & Business Administration & -.37054 & .22119 & .096 & -.8084 & .0673 \\
\hline & Engineering & .13571 & .18275 & .459 & -.2260 & .4975 \\
\hline & Information Technology & .18571 & .25025 & .459 & -.3096 & .6811 \\
\hline \multirow{4}{*}{$\begin{array}{l}\text { Business } \\
\text { Administration }\end{array}$} & dentistry & .11678 & .18012 & .518 & -.2398 & .4733 \\
\hline & $\begin{array}{l}\text { Pharmacy \& Health } \\
\text { Science }\end{array}$ & .37054 & .22119 & .096 & -.0673 & .8084 \\
\hline & Engineering & $.50625^{*}$ & .17360 & .004 & .1626 & .8499 \\
\hline & Information Technology & $.55625^{*}$ & .24364 & .024 & .0740 & 1.0385 \\
\hline \multirow[t]{4}{*}{ Engineering } & dentistry & $\begin{array}{c}-.38947- \\
*\end{array}$ & .13007 & .003 & -.6469 & -.1320 \\
\hline & $\begin{array}{l}\text { Pharmacy \& Health } \\
\text { Science }\end{array}$ & -.13571 & .18275 & .459 & -.4975 & .2260 \\
\hline & Business Administration & $\begin{array}{l}-.50625- \\
*\end{array}$ & .17360 & .004 & -.8499 & -.1626 \\
\hline & Information Technology & .05000 & .20937 & .812 & -.3644 & .4644 \\
\hline \multirow[t]{4}{*}{$\begin{array}{l}\text { Information } \\
\text { Technology }\end{array}$} & dentistry & $\begin{array}{c}-.43947- \\
*\end{array}$ & .21481 & .043 & -.8647 & -.0143 \\
\hline & $\begin{array}{l}\text { Pharmacy \& Health } \\
\text { Science }\end{array}$ & -.18571 & .25025 & .459 & -.6811 & .3096 \\
\hline & Business Administration & $\begin{array}{c}-.55625- \\
*\end{array}$ & .24364 & .024 & $\begin{array}{c}- \\
1.0385\end{array}$ & -.0740 \\
\hline & Engineering & -.05000 & .20937 & .812 & -.4644 & .3644 \\
\hline
\end{tabular}

The results of Table 11 showed that the source of the differences from the perspective of faculty members' according to college variable was in favor of the faculty members of Business Administration College.

- Academic Rank: Relating to Academic Rank, Table 12 shows the resulting Analysis of variance according to Academic rank variable by One Way ANOVA test for the faculty members' responses.

It is clear from Table 12 that there are not statistically significant differences at the level of (0.145) and is bigger than the required statistical significance level (0.05); from the perspective of faculty Members' according to Academic rank variable.

- Experience: Relating to Experience, Table 13 shows the resulting Analysis of variance according to experience variable by One Way ANOVA test for the faculty members' responses. 
- It is clear from table 13 that there are not statistically significant differences at the level of (0.410) and is bigger than the required statistical significance level (0.05); from the perspective of faculty Members' according to experience variable.

Table 12. The resulting Analysis of variance according to Academic rank variable by One Way ANOVA test.

\begin{tabular}{|l|l|c|c|c|c|c|l|}
\hline & & Sum of Squares & df & $\begin{array}{c}\text { Mean } \\
\text { Square }\end{array}$ & F & Sig (tailed) & Sig. level \\
\hline \multirow{2}{*}{$\begin{array}{l}\text { Academic } \\
\text { Rank }\end{array}$} & Between Groups & 2.139 & 3 & 0.713 & 1.829 & 0.145 & $\begin{array}{l}\text { Not } \\
\text { Significant }\end{array}$ \\
\cline { 2 - 6 } & Within Groups & 48.328 & 124 & 0.390 & & & \\
\cline { 2 - 6 } & Total & 50.467 & 127 & & & & \\
\hline
\end{tabular}

Table 13.

The resulting Analysis of variance according to experience variable by one way ANOVA test.

\begin{tabular}{|l|l|c|c|c|c|c|l|}
\hline & & $\begin{array}{c}\text { Sum of } \\
\text { Squares }\end{array}$ & df & $\begin{array}{c}\text { Mean } \\
\text { Square }\end{array}$ & F & Sig (tailed) & Sig. level \\
\hline College & Between Groups & 0.714 & 2 & 0.357 & 0.410 & .897 & $\begin{array}{l}\text { Not } \\
\text { Significant }\end{array}$ \\
\hline & Within Groups & 49.753 & 125 & 0.398 & & & \\
\hline & Total & 50.467 & 127 & & & & \\
\hline
\end{tabular}

\section{Conclusion}

The results of the study showed that there is a medium degree of application of etextbooks and that e-textbooks have an average medium impact on student achievement. The results also showed that the degree of application vary from the perspective of faculty members' according to gender which was in favor of the female, and according to college variable was in favor of the Business Administration college. Further, the results showed that there are not statistically significant differences according to academic rank variable and experience variable. The orientation of higher education institutions towards using technology in teaching and learning process will increase the opportunities of using e-textbooks therefor, the faculty members agree on the need to develop and improve the features and requirements of e-textbooks that have been applied. The findings led to recommendations including the implementation of a training program on e-textbooks for the faculty members' and students focusing on the features, applications and options of e-textbooks. 


\section{Recommendations}

In light of the results of the study, some recommendations have been made: -

- The university should adopt the idea of implementing a training program on etextbooks for the faculty members' and students.

- The university should conduct a thorough review about the e-textbooks requirements and features in order to ensure that all requirements are available according to international standards.

- Conduct further research on the application and using of e-textbooks in all education institutions.

\section{References}

[1] Plangsorn, B. \& Poopan, S. (2017). Development of producing and using e-books competencies of teachers in Chachengsao, Thailand. World Journal on Educational Technology. 9(2), 112-117. https://doi.org/10.18844/wjet.v9i2.690

[2] Thomas, S. E. (2007). Another side of the e-book puzzle. Indiana Libraries, 26(1), 3945.

[3] Vallejo, N, Vargas, O, Luis, R. (2018). Effect of Motivational Scaffolding on E-Learning E-Environments: Self-Efficacy, Learning Achievement, and Cognitive Style, Journal of Educators Online, v15. https://doi.org/10.9743/jeo2018.15.1.5

[4] Alshaya, Fahd bin Suleiman. (2010). The impact of the use of e-books on the development of creative thinking and the trend towards the use of computers in the biology of secondary school students secondary in Riyadh. Sana'a University Journal of Educational and Psychological Sciences. Volume (7), Issue (1).

[5] Lee, H, Messom, C, Yau, K. (2013). Can an electronic textbook be part of K-12 education? Challenges, technological solutions and open issues. Turkish Online Journal of Educational Technology, volume 12 Issue 1.

[6] Khalid, S., Mary, 1. Anisa, H. Zainab, S., \& Mariam, W. (2017). Are We Ready for E-books? Omani University Students' Uses and Perceptions of E-books. The Turkish Online Journal of Educational Technology, volume 16 issue 2, Retrieved March 10, 2018. https://eric.ed.gov/?id=EJ1137777

[7] Chris, Armstrong, and Edwards, Louise and Ray, Lonsdale. (2002). Virtually There? Ebooks in UK academic libraries. Program: electronic library and information systems, vol. 36, n. 4, pp. 216-227. https://doi.org/10.1108/00330330210447181

[8] Vassiliou, M. (2008). Progressing the definition of "e-book". Library Hi Tech, 26(3),355368. https://doi.org/10.1108/07378830810903292

[9] Chen, H. \& Jang, S. (2013). Exploring the reasons for using electronic books and technologic pedagogical and content knowledge of Taiwanese elementary mathematics and science teachers. The Turkish Online Journal of Educational Technology, volume 12 Issue 2.

[10] Bunkell, J., \& Dyas-Correia, S. (2009). E-books vs. print: Which is the better value? The Serials Librarian, (56), 215-219. https://doi.org/10.1080/03615260802698283

[11] Jones, T., \& Brown, C. (2011). Reading engagement: A comparison between e-books and traditional print books in an elementary classroom. International Journal of Instruction, 4(2), Retrieved December 27, 2017 from ERIC database. (ED522678). https://eric.ed. gov/?id=EJ1064659 
[12] Foster, G., \& Remy, E. (2009). E-books for academe: A study from Gettysburg College Research Bulletin. Issue 21: EDUCAUSE Center for Applied Research, pp., 2-13. Retrieved January 4, 2018. https://www.educause.edu/ir/library/pdf/ERB1002.pdf

[13] Alshaya, H., \& Oyaid, A. (2017). Designing and Publication of Interactive E-Book for Students of Princess Nourah Bint Abdulrahman University: An Empirical Study. Journal of Education and Practice, 8(8), 41-57.

[14] Ebied, M. M. A., \& Rahman, S. A. (2015). The Effect of Interactive e-Book on Students' Achievement at Najran University in Computer in Education Course. Journal of Education and Practice, 6(19), 71-82.

[15] Yalman, M. (2015). Preservice Teachers' Views about e-book and Their Levels of Use of ebooks. Procedia-Social and Behavioral Sciences, 176, 255-262. https://doi.org/10.1 016/j.sbspro.2015.01.469

[16] Berg, S.A., Hoffmann, K., \& Dawson, D. (2010). Not on the same page: Undergraduates' information retrieval in electronic and print books. The Journal of Academic Librarianship, 36 (6), 518-525. https://doi.org/10.1016/j.acalib.2010.08.008

[17] Oliveira, S. M. (2012). e-Textbooks Usage by Students at Andrews University: A Study of Attitudes, Perceptions, and Behaviors.

[18] Beimers, D. (2014). Correlation between Interactive e-Books and Printed Text in Reading Achievement and Student Interest). Master of Education Program Theses. Paper 48.

[19] Kennedy, Z., \& Chiasson, S. (2016, June). Teaching with an Interactive E-book to Improve C Children's Online Privacy Knowledge. In Proceedings of the The15th International Conference on Interaction Design and Children (pp. 506-511). ACM. https://doi.org/10.1 $\underline{145 / 2930674.2935984}$

\section{Authors}

Mohd Elmagzoub Eltahir, Ph.D. is an Assistant Professor of Educational Technology, Education Department, College of Humanities and Sciences at Ajman University. Dr. Eltahir Performs Scientific Research in E-Learning, Educational Technology, and Multimedia in Education. He has Significant Consultancy Experience in The Fields of Using Technology in Education, in Different Schools in U.A.E. He Received the Sharjah Award for Excellence in Education in 2009.

Sami Al-Qatawneh, Ph.D. is an Assistant Professor of Curriculum and Methods of Teaching at College of Humanities and Sciences, Ajman university, Ajman, UAE.

Najeh Alsalhi, Ph.D. is a research assistant at the College of Humanities and Sciences, Ajman university, Ajman, UAE.

Article submitted 2018-09-04. Resubmitted 2019-02-11. Final acceptance 2019-03-18. Final version published as submitted by the authors. 